\title{
APRESENTAÇÃO \\ PATRIMÔNIO CULTURAL: A CONSTRUÇÃO DO CONHECIMENTO E A EXTENSÃO UNIVERSITÁRIA
}

A Revista CPC, ao longo de seus dez anos de circulação, vem contribuindo sistematicamente à reflexão sobre o patrimônio cultural sob uma condição que lhe é peculiar: é um dos poucos periódicos editados por um órgão de extensão universitária. Sua vinculação ao Centro de Preservação Cultural da USP, da Pró-Reitoria de Cultura e Extensão Universitária, sediado desde 2004 fora da Cidade Universitária, em um bairro culturalmente de grande interesse - tanto que tombado pelo CONPRESP -, não é apenas de uma questão de organograma administrativo, mas sobretudo, uma condição do olhar que têm influído muito no desenvolvimento dos trabalhos do CPC-USP, incluindo aí a revista. A troca entre o conhecimento científico, o saber prático e a convivência com a dinâmica de um bairro tombado tem proporcionado constante questionamento e reflexão dos princípios e teorias consolidadas no meio acadêmico, gerando significativo avanço no debate sobre cultura e sobre patrimônio. Os cursos, seminários, oficinas, exposições e a revista atendem a uma demanda cada vez mais ampliada e diversificada, criando uma rara oportunidade de diálogo entre o corpo docente, pesquisadores e técnicos, e a sociedade não acadêmica. 
Até recentemente, no campo do patrimônio cultural, a contribuição no âmbito da extensão universitária resumia-se a pareceres, consultorias, sendo a mais reconhecida a participação do corpo docente no órgão de preservação estadual - CONDEPHAAT, que conta com representantes de quatro departamentos: geografia, história, história da arquitetura e ciências sociais, das três universidades estaduais: USP, UNICAMP e UNESP, cujo embasamento teórico constitui fundamental apoio na elaboração de pareceres e nas avaliações dos processos de tombamento. Mesmo com embates muito ricos e polêmicos, é ainda uma troca entre especialistas.

Os trabalhos do CPC-USP vêm ampliando, de forma sistemática, essas relações. São parcerias com artistas locais em atividades com moradores do bairro; com escolas, para ações conjuntas de educação sobre o patrimônio; com colecionadores que abrem seus arquivos; além dos cursos dirigidos para os professores de ensino médio, para interessados fora do meio acadêmico, que têm trazido situações inusitadas ao campo disciplinar. A Revista CPC tem cumprido o papel de extroversão e alargamento do debate. Esta edição de número 22 traz dez artigos com temas que abrangem da escala urbana ao objeto, com problematizações diversas, de nove procedências distintas.

Os dois primeiros artigos apresentam as dificuldades de reconhecimento e da conservação do patrimônio moderno. A casa modernista de Flávio de Carvalho: arte, política e um território em disputa?, por Pedro Luiz Stevolo, analisa uma casa ícone, não só da arquitetura moderna, mas das vanguardas artísticas de meados do século 20 na cidade de São Paulo que, apesar de tombada, não conta com qualquer apoio do poder público. $O$ cavalo de batalha moderno: [r]existências, debates e possibilidades em torno do caso do Hotel internacional Reis Magos, de George Alexandre Ferreira Dantas; José Clewton do Nascimento e Natália Miranda Vieira-de-Araújo, sobre um hotel que é um importante marco para o desenvolvimento do turismo em Natal em meados dos anos 1960, ameaçado de ser demolido.

Sobre o debate das questões conceituais, Andréa de Oliveira Tourinho e Marly Rodrigues retomam as ideias sobre Patrimônio Ambiental Urbano lançadas e discutidas nos anos 1970-1980, que ficaram restritas à gestão territorial, apesar do envolvimento de profissionais de distintas formações. A recuperação do histórico desse conceito pode ser um bom subsídio às discussões atuais que, segundo as autoras, enfrentam o reconhecimento 
de identidades diversas. Tão atual é essa discussão que os quatro artigos seguintes tratam do patrimônio urbano, segundo óticas distintas. Em Se Camillo Sitte visitasse o Rio de Janeiro? Claudio Antonio Santos Lima Carlos analisa, a partir das teorias do urbanista vienense Camillo Sitte, duas situações urbanas no Rio de Janeiro: a Igreja da Candelária e o portão principal de acesso ao Jardim da Quinta da Boavista. A relação desses monumentos com o entorno circundante é foco da interpretação das teorias de Sitte. No artigo intitulado Apropriações e percepções sobre o bairro histórico de Paraty- RJ, Mariana Freitas Priester discute a repercussão das intervenções do Iphan no conjunto histórico de Paraty a partir de uma pesquisa com moradores, tendo sido recorrentemente por eles associada à ideia de identidade e tradição. Liliane de Castro Vieira questiona essa construção historiográfica em Ouro Preto e o século XIX: o mito da decadência, argumentando a partir de documentos que a cidade se manteve muito dinâmica nos 1800 com o comércio e as atividades artesanais, culminado com a inauguração da ferrovia em 1888. Também tendo a ferrovia como parâmetro de modernização do interior do país, Taís Schiavon descreve o papel da ferrovia Estrada de Ferro Noroeste do Brasil, localizada na região Oeste do Estado de São Paulo, no processo de urbanização da região Oeste do Estado de São Paulo e da internacionalização do sistema produtivo, identificando a importância da ferrovia como registro desse processo. Fecha o tema do patrimônio urbano o artigo A construção da cidade, a urbanidade e o patrimônio ambiental urbano: o caso do Bexiga, no qual Nádia Somekh defende o conceito de patrimônio ambiental urbano para a preservação do bairro do Bexiga, alegando que é a apropriação dos espaços públicos que produz urbanidade; e que é a participação e o diálogo na identificação e proteção do patrimônio que construirá o futuro das cidades.

Sob a ótica das referências culturais, Francimário Vito dos Santos analisa, no artigo A política de registro das congadas em Minas Gerais: mobilização, diálogos e descontinuidades em Santo Antônio do Monte/MG, o processo para o pedido de registro de uma prática cultural através da metodologia específica denominada de INRC - Inventário Nacional de Referências Culturais, recuperando a condução do processo de mobilização da base social, com diálogos institucionais entre estado e congadeiros e possíveis descontinuidades da política. 
Encerrando a sessão de artigos, João Lorandi Demarchi identifica no texto Perspectivas para atuação em educação patrimonial uma falta de embasamento teórico nas discussões sobre o tema, e propõe uma sistemática reflexão sobre o tema com o objetivo de construir novas possibilidades de atuação.

Na sessão notícias, são comentados algumas das atividades promovidas pelo CPC-USP. O seminário escaneamento laser em três dimensões para bens arquitetônicos: características e possibilidades de uso, sob a coordenação da Profa. Dra. Beatriz Kuhl, trouxe a público os trabalhos realizados no edifício da FAU-USP por um grupo de professores e pesquisadores da Universidade de Ferrara, ligados ao Development of Integrated Automatic Procedures for Restoration of Monuments (DIAPReM). Essa atividade tinha por objetivo a formação de pesquisadores da FAU-USP para o uso de técnicas digitais para registro, interpretação e modelagem eletrônica de bens arquitetônicos e conjuntos urbanos, que contribuirá muito para o restauro do patrimônio arquitetônico. E a Casa de Dona Yayá, após permanecer fechada por ao longo de 2016 para as obras de acessibilidade, reabriu ao público com duas exposições: Infinitas Cores do Bixiga na Yayá e Yayá, um lugar de memória, sob a curadoria do arquiteto Gabriel Fernandes. A primeira é resultado de uma oficina de arte naif coordenada pelo artista plástico Arieh, e a segunda, de caráter permanente, vem atender a uma recorrente solicitação dos visitantes de maiores informações sobre Dona Yayá. A partir da documentação existente, construiu-se uma linha do tempo dessa personagem, suscitando aos leitores novas leituras dessa trajetória.

Espero que os textos a seguir agucem a curiosidade e despertem novas questões. Mônica Junqueira de Camargo 